\title{
Gambaran Tingkat Pengetahuan Ibu Tentang Imunisasi Vaksin Measles Rubella (MR) di UPT Blud Puskesmas Gunungsari Periode Agustus 2019.
}

\author{
Yuli Fitriana ${ }^{a, 1 *}$, Nur Furqani ${ }^{a, 2}$, Siti Maryam Ulfa ${ }^{\text {a, } 3}$ \\ a,1,2 Dosen Program Studi Diploma Tiga Farmasi, Universitas Muhammadiyah Mataram, Mataram, Indonesia \\ a,3 Mahasiswa Program Studi Diploma Tiga Farmasi, Universitas Muhammadiyah Mataram, Mataram, Indonesia \\ 3sitimaryamulfa1997@gmail.com \\ *korespondensi penulis
}

\begin{tabular}{ll}
\hline INFO ARTIKEL & ABSTRAK \\
\hline Diterima : & Campak dan Rubella merupakan penyakit infeksi menular melalui saluran nafas \\
I6-I2-20I9 & yang disebabkan oleh virus Campak dan Rubella.Batuk dan bersin dapat menjadi \\
Disetujui : & jalur masuknya virus campak maupun rubella. Pengetahuan vaksin MR adalah \\
23-I2-20I9 & $\begin{array}{l}\text { kombinasi vaksin Campak/Measles (M) dan Rubella (R) untuk perlindungan } \\
\text { terhadap kedua penyakit tersebut Campak dan rubella merupakan jenis penyakit }\end{array}$ \\
\hline Kata kunci : & yang tidak dapat di obati (virus penyebab penyakit tidak dapat dibunuh), maka \\
Tingkat Pengetahuan; & imunisasi MR ini adalah pencegahan terbaik bagi keduanya. Tujuan penelitian \\
Imunisasi; & untuk mengetahui gambaran tingkat pengetahuan ibu tentang imunisasi vaksin \\
Masles Rubella; & measles rubella (MR) di UPT BLUD puskesmas gunungsari periode 20I9. \\
Puskesmas. & Penelitian ini merupakan penelitian observasional deskriptif dengan mengambil \\
& data secara cross sectional, populasi sebanyak 458, diperoleh sampel sebanyak \\
& 82 responden yang dipilih secara purposive sampling mengunakan data primer. \\
& Hasil penelitian menunjukkan bahwa gambaran tingkat pengetahuan ibu tentang \\
imunisasi vaksin measles rubella yaitu 58,8\%.
\end{tabular}

Keywords :

Knowledge Level;

Immunization;

Masles Rubella;

Puskesmas

\begin{abstract}
Measles and Rubella are infectious diseases transmitted through the airways caused by the Measles and Rubella viruses. Coughing and sneezing can be a pathway for measles and rubella viruses. Knowledge $M R$ vaccine is a combination of Measles (M) and Rubella (R) vaccines for protection against both The disease Measles and rubella are types of diseases that can not be treated (the virus that causes the disease can not be killed), then MR immunization is the best prevention for both. The purpose of this research is to find out the description of mothers' knowledge about immunization Measles Rubella (MR) vaccine in UPT BLUD puskesmas gunungsari period 2019. This research is a descriptive observational study by taking cross sectional data, a population of 458 , obtained a sample of 82 respondents selected by purposive sampling using primary data. The results showed that the level of knowledge of mothers about measles rubella vaccine immunization was $58.8 \%$.
\end{abstract}

\section{PENDAHULUAN}

Campak merupakan penyakit menular yang disebabkan oleh virus genus Morbillivirus ${ }^{[I]}$. Gejala campak muncul sekitar 10 hari setelah infeksi, dan ruam coklat kemerahan muncul sekitar 14 hari setelah infeksi ${ }^{[2]}$. Rubella merupakan masalah kesehatan yang mempunyai berbagai dampak klinis dan dapat memberikan dampak buruk baik berupa mortalitas dan morbiditas ${ }^{[3]}$.

Berdasarkan data yang dipublikasi Badan Kesehatan Dunia WHO tahun 2015, Indonesia termasuk 10 negara dengan jumlah kasus campak terbesar di dunia. Kementrian Kesehatan RI mencatat jumlah kasus Campak dan Rubella yang ada di Indonesia sangat banyak dalam kurun waktu lima tahun terakhir ${ }^{[4]}$.

Imunisasi MR (Measles Rubella) sangat penting dan aman diberikan kepada anak. Menurut Fatwa Majelis Ulama Indonesia (MUI) nomor 4 tahun 2016 dijelasakan bahwa imunisasi pada dasarnya dibolehkan sebagai bentuk ikhtiar untuk mewujudkan kekebalan tubuh dan mencegah 
terjadinya suatu penyakit tertentu ${ }^{[5]}$. Vaksin MR (Measles Rubella) memberikan manfaat seperti dapat melindungi anak dari kecacatan dan kematian akibat komplikasi pneumonia, diare, kerusakan otak, ketulian, kebutaan dan penyakit jantung bawaan (Ditjen P2P, 2016) ${ }^{[6]}$.

Di Indonesia Vaksin Measles Rubella (MR) yang beredar mengandung unsur $\mathrm{Babi}^{[7]}$. Ditinjau dari komposisi vaksin Measles Rubella (MR) yang terdiri atas gelatin yang berasal dari kulit babi dan Typsin yang berasal dari pankreas babi, bahan lain yang berpeluang besar bersentuhan dengan babi dalam proses produksinya yaitu laktabumin hydrolysate, serta terdapat pula bahan yang berasal dari tubuh manusia (Human diploid cell) ${ }^{87}$.

\section{METODE PENELITIAN}

Penelitian ini dilakukan dengan menggunakan metode penelitian observasional deskriptif. Pengumpulan data dapat dilakukan dengan pendekatan cross sectional. Cross sectional, yaitu dengan cara pengunpulan data sekaligus pada satu waktu $^{[9]}$. Penelitian ini dilakukan di UPT BLUD Puskesmas Gunungsari Jalan Priwisata No.70, Kec. Lombok Barat. Kriteria Inklusi Ibu yang membawa anaknya untuk imunisasi vaksin Measles Rubella $(M R)$. Jenis data dalam penelitian ini adalah data primer. Data primer di peroleh melalui penyebaran kuesioner kepada responden pada bulan Agustus tahun 2019.

\section{HASIL DAN PEMBAHASAN}

\section{Karakteristik Subjek Penelitian}

Penelitian ini dilakukan di Puskesmas Gunungsari yang beralamat J1. Pariwisata No. 70, Gn. Sari, kabupaten Lombok Barat, Nusa Tenggra Barat, penelitian dilakukan pada tanggal 5 Agustus 2019. Subjek pada penelitian ini adalah ibu yang membawa anak untuk imunisasi vaksin Measles Rubella (MR) yang sesuai dengan kriteria insklusi sebanyak 82 responden dilakukan pengujian yaitu berdasarkan usia, pendidikan, pekerjaan dan tingkat pengetahuan.

Pada bab ini peneliti akan menyajikan hasil penelitian dan pembahasan dari pengumpulan data kuesioner yang disertai dengan wawancara tentang Gambar tingkat pengetahuan ibu tentang imunisasi vaksin Measles Rubella ( $M R$ ) di UPT BLUD puskesmas gunungsi Karakteristik Responden subjek penelitian terlihat pada tabel 4.I sebagai berikut :

Tabel 4.I. Karakteristik Responden subjek penelitian

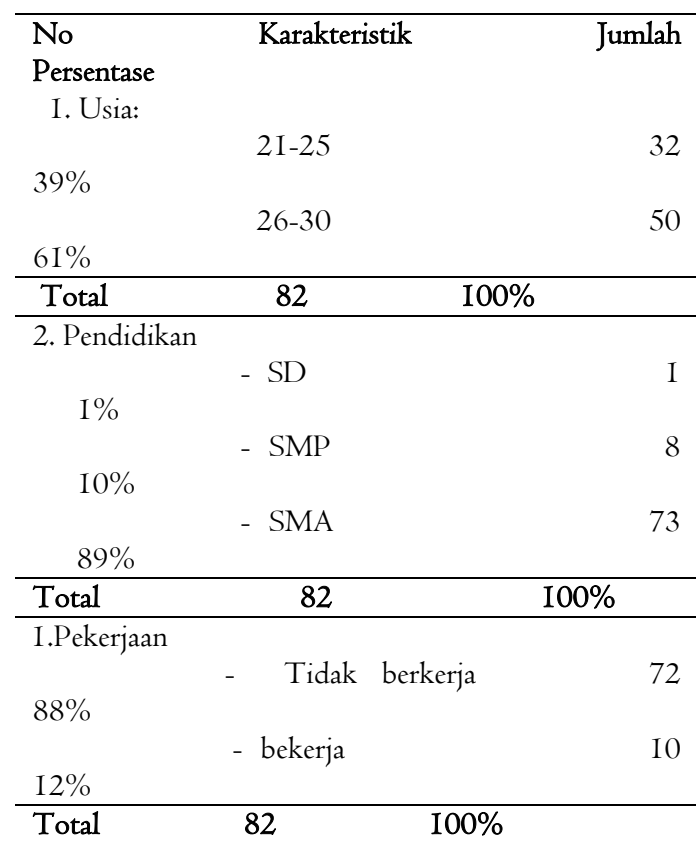

Distribusi berdasarkan table 4.I hasil penelitian menunjukan bahwa sebagian responden berusia 2I-25 tahun sebanyak 32 orang (39\%), dan usia 26-30 tahun sebanyak 50 orang (6I\%). Orang yang lebih cukup umur, tingkat kekuatan seseorang akan lebih matang dalam berpikir dan mempunyai daya ingat yang lebih kuat, mengenal sesuatu yang belum diketahui dibandingkan dengan responden yang lebih muda disamping itu usia yang terlalu muda sehinnga pematangannya belum terlalu matang dalam memilikirkan manfaat imunisasi vaksin Measles Rubella (MR).

Hasil penelitian ini sedikit berbeda dengan penelitian yang dilakukan oleh huclok (I998) dalam Wawan (20I0), semakin cukup umur, tingkat kematangan dan kekuatan seseorang akan lebih matang dalam berpikir dan bekerja. Dalam penelitian ini umur responden yang terlalu muda sehingga pematangannya belum terlalu matang dalam memikirkan manfaat imunisasi Measles Rubella (MR) bagi anaknya sendiri.

Distribusi berdasarkan table $4 . I$ tentang karakteristik responden berdasarkan tingkat pendidikan diperoleh hasil dari tingkat pendidikan SD sebanyak I orang (I\%) SMP sebanyak 8 orang (I0\%) berpendidikan SMP sebanyak 8 orang (I0\%) berpendidikan SMA sebanyak 73 orang (89\%) dan terakhir pendididkan PT (Perguruan Tinggi) sebanyak 0 responden ( $0 \%)$.

Berdasarkan hasil penelitian yang dilakukan oleh Ramali A, (20I0) dengan kepatuhan ibu tentang perbedaan antara tingkat pengetahuan ibu dengan pendidikan tinggi (PT, SMA) maupun sedang (SMP dan SD), pada 
penelitian ini lebih banyak ibu yang berpendidikan SMA memiliki pengetahuan yang cukup dibanding pada ibu dengan pendidikan SD dan SMP. Pendidikan merupakan proses perubahan sikap dan tingkah laku seseorang atau kelompok orang dalam usaha mendewasakan manusia melalui pengajaran, latihan, proses, perbuatan dan cara mendidik.

Distribus berdasarkan table $4 . I$ tentang karakteristik responden berdasarkan pekerjaan dikelompokan menjadi 2 katagori yaitu berkerja dan tidak berkerja. penelitian ini didominasi oleh kelompok responden yang tidak bekerja sebanyak 72 orang ( $88 \%)$ dibandingkan dengan pasien yang bekerja sebanyak IO orang (I2\%). Hal ini berkaitan dengan pasien mayoritas perempuan, dimana sebagian besar pekerjaan yaitu tidak bekerja atau hanya sebagai ibu rumah tangga sebanyak 72 responden ibu (88\%).

Ibu rumah tangga dimasukkan dalam klasifikasi tidak bekerja, sementara bekerja dikaitkan dalam masalah ekonomi. Namun meskipun responden sebagai ibu rumah tangga bukan berarti reponden kehilangan kesempatan untuk meningkatkan ilmu pengetahuannya khusus pada imunisa vaksin Measles Rubella (MR). Responden yang lebih banyak dirumah tetap dapat menambah pengetahuan melalui berbagai media, seperti dari televisi, membaca koran, tentang masalah kesehatan, ataupun mengunjungi ke petugas kesehatan untuk memperoleh informasi tentang imunisa vaksin Measles Rubella (MR). Wanita yang bekerja diluar rumah juga akan lebih banyak mendapatkan informasi dari orang lain sekitar dibanding wanita yang hanya mengabdikan diri untuk keluarganya (Ahmad, Syafiq, Ir.d kk. 20I0).

\section{Distribusi frekuensi tingkat pengetahuan responden berdasarkan Umur, Tingkat Pendidikan Dan Pekerjaan}

Pada hasil distribus frekuensi tingkat pengetahuan responden berdasarkan umur, tingkat pendidikan dan perkerjaan di UPT BLUD P uskesmas Gunungsari periode Agustus 2019.

a. Distribusi Frekuensi Tingkat Pengetahuan Responden Berdasarkan Usia

Distribusi tingkat pengetahuan berdasarkan usia pada tabel 4.2, menunjukkan bahwa pada kelompok usia 2I-25 tahun terdapat I responden (I,22\%) yang memiliki tingkat pengetahuan sangat baik, I7 responden $(20,7 \%)$ yang memiliki tingkat pengetahuan baik, II responden (I3,4\%) yang memiliki tingkat pengetahuan cukup, 3 responden $(3,7 \%)$ yang memiliki tingkat pengetahuan kurang dan
0 responden (0\%) yang mempunyai tingkat pengetahuan sangat kurang. Pada kelompok usia 26-30 tahun, terdapat I responden (I,22\%) yang memiliki tingkat pengetahuan sangat baik, I8 responden $(22,0 \%)$ yang memiliki tingkat pengetahuan baik, 24 responden (29,3\%) yang memiliki tingkat pengetahuan cukup, 6 responden $(7,3 \%)$ dan $\mathrm{I}$ responden ( $1,5 \%$ ) yang memiliki tingkat pengetahuan sangat buruk.

Hasil penelitian Notoatmodjo (2007) tersebut menunjukan bahwa Gambaran tingkat pengetahuan ibu tentang imunisasi Measles Rubella (MR) di UPT BLUD Puskesmas Gunungsari berdasarkan usia 26, tampak bahwa responden yang paling banyak memiliki tingkat pengetahuan baik yaitu terdapat pada kelompok usia 26-30 tahun. usia mempengaruhi terhadap daya tangkap dan pola pikir seseorang. Semakin bertambah usia akan semakin berkembang pula daya tangkap dan pola pikirnya, sehingga pengetahuan yang diperolehnya semakin membaik. individu akan lebih berperan aktif dalam masyarakat dan kehidupan sosial serta lebih banyak melakukan persiapan demi suksesnya upaya menyesuaikan diri menuju usia tua, selain itu orang pada usia ini akan lebih banyak menggunakan banyak waktu untuk membaca. Kemampuan intelektual, pemecahan masalah, dan kemampuan verbal dilaporkan hampir tidak ada penurunan pada usia ini .

b. Distribusi Frekuensi Tingkat Pengetahuan Responden Berdasarkan Tingkat Pendidikan

Pada tabel 2 Distribusi frekuensi tingkat pengetahuan responden berdasarkan tingkat pendidikan menunjukkan bahwa pada tingkat pendidikan SD terdapat I responden (I,22\%) yang memiliki tingkat pengetahuan sangat baik, 0 responden $(0 \%)$ yang memiliki tingkat pengetahuan baik, I responden (I,2\%) yang memiliki tingkat pengetahuan cukup, 0 responden (0\%) yang memiliki tingkat pengetahuan kurang, dan terdapat 0 responden $(0 \%)$ yang memiliki tingkat pengetahuan sangat kurang. Pada tingkat pendidikan SMP terdapat 0 responden ( $0 \%$ ) yang memiliki tingkat pengetahuan sangat baik, 6 responden $(7,3 \%)$ yang memiliki tingkat pengetahuan baik, 2 responden $(2,4 \%)$ yang memiliki tingkat pengetahuan cukup dan yang memiliki tingkat pengetahuan kurang dan sangat kurang memiliki 0 responden $(0 \%)$.

Pada tingkat pendidikan SMA, terdapat I reponden (I,22\%) yang memiliki tingkat pengetahuan sangat baik, 29 responden 
$(35,4 \%)$ yang memiliki tingkat pengetahuan baik, 32 responden (39,0\%) yang memiliki tingkat pengetahuan cukup, 8 responden $(9,8 \%)$ yang memiliki tingkat pengetahuan kurang dan dengan tingkat pengetahuan sangat kurang dengan 2 responden (2,4\%). Dan pada tingkat perguruan tinggi terdapat 0 responden $(0 \%)$ yang memiliki tingkat pengetahuan sangat baik, 0 responden ( $0 \%$ ) yang memiliki tingkat pengetahuan baik, 0 responden $(0 \%)$ yang memiliki tingkat pengetahuan cukup 0 responden $(0 \%)$ dan yang memiliki tingkat pengetahuan kurang dan sangat kurang memiliki 0 responden $(0 \%)$.

Gambaran tingkat pengetahuan ibu tentang imunisasi vaksin imunisasi Measles Rubella $(M R)$ berdasarkan tingkat pendidikan, bahwa mayoritas responden yang berpengetahuan sangat baik berada pada tingkat pendidikan SD dan SMA dimana terdapat I reponden (I,2\%), responden yang berpengetahuan baik terbanyak berada pada tingkat pendidikan SMA dengan jumlah 29 responden $(35,4 \%)$, responden yang berpengetahuan cukup terbanyak berada pada tingkat pendidikan SMA dengan jumlah 32 responden (39\%), responden yang berpengetahuan kurang terbanyak berada pada tingkat pendidikan SMA dengan jumlah 8 responden $(9,8 \%)$, dan responden yang memiliki pengetahuan sangat kurang terdapat pada tingkat pendidikan SMA 2 responden (2,4\%).

Berdasarkan penelitian Mahmudah (2007) yang mengatakan bahwa Pendidikan mempengaruhi tingkat pengetahuan ibu karena semakin tinggi tingkat pendidikan ibu maka semakin banyak pula informasi yang diperoleh. Pengetahuan ibu tentang imunisasi tersebut bisa diperoleh baik melalui pendidikan formal maupun pendidikan non formal. Sebagai contoh pendidikan formal yaitu dengan mengikuti pendidikan di sekolah kesehatan dan pendidikan non formal yaitu melalui informasi yang diperoleh ibu baik secara langsung maupun tidak lansung seperti iklan dan penyuluhan. Sebagai contoh ibu yang mempunyai tingkat pendidikan SMA maka tingkat pengetahuannya akan lebih baik daripada ibu yang memiliki tingkat pendidikan SMP.

c. Distribusi Frekuensi Tingkat Pengetahuan Responden Berdasarkan Pekerja

Pada tabel 4.5 menunjukkan bahwa pada kelompok pekerjaan yaitu tidak bekerjaan terdapat I responden (I,2\%) yang memiliki tingkat sangat baik, 32 responden (39\%) yang memiliki pengetahuan baik, 29 responden $(35,4 \%)$ yang memiliki tingkat pengetahuan cukup, 9 responden (II\%) yang memiliki tingkat pengetahuan kurang dan I responden (I,2\%) yang memiliki tingkat pengetahuan sangat kurang. Pada kelompok bekerjaan, terdapat terdapat I responden (I,2\%) yang memiliki tingkat sangat baik, 3 responden (3,7\%) yang memiliki tingkat pengetahuan baik, 6 responden $(7,3 \%)$ yang memiliki tingkat pengetahuan cukup, dan tingkat pengatuan kurang dan sangat kurang terdapat 0 responden $(0 \%)$.

Gambaran tingkat pengetahuan ibu tentang imunisasi Measles Rubella (MR) berdasarkan pekerjaan, tampak bahwa mayoritas responden yang berpengetahuan sangat baik berada pada tidak bekerja dan bekerja dimana terdapat I reponden ( $\mathrm{I}, 2 \%)$, responden yang berpengetahuan baik terbanyak berada pada pekerjaan IRT dengan jumlah 32 responden (39,0\%), responden yang berpengetahuan cukup terbanyak berada pada pekerjaan IRT dengan jumlah 29 responden $(35,4 \%)$, responden yang berpengetahuan kurang terbanyak berada pada pekerjaan IRT dengan jumlah 9 responden ( $\mathrm{I}, 0 \%$ ), dan responden yang memiliki pengetahuan sangat kurang terdapat pada tingkat pekerjaan IRT I responden ( $\mathrm{I}, 2 \%)$.

Ibu rumah tangga dimasukkan dalam klasifikasi tidak bekerja, sementara bekerja dikaitkan dalam masalah ekonomi. Namun meskipun responden sebagai ibu rumah tangga bukan berarti reponden kehilangan kesempatan untuk meningkatkan ilmu pengetahuannya khusus pada imunisasi Measles Rubella (MR). Responden yang lebih banyak dirumah tetap dapat menambah pengetahuan melalui berbagai media, seperti dari televisi, membaca koran, tentang masalah kesehatan, ataupun mengunjungi ke petugas kesehatan untuk memperoleh informasi tentang diare. Wanita yang bekerja diluar rumah juga akan lebih banyak mendapatkan informasi dari orang lain sekitar dibanding wanita yang hanya mengabdikan diri untuk keluarganya (Ahmad,Syafiq,Ir.dkk.2010).

\section{Tingkat Pengetahuan Tentang Imunisasi Measles Rubella(MR)Berdasarkan Subjek Penelitian}

Berdasarkan hasil penelitian ini, dengan jumlah responden 82 orang yang dilibatkan dalam penelitian dengan menggunakan kuesioner 
penelitian di sertai dengan wawancara tentang tingkat pengetahuan ibu tentang imunisasi vaksin Measles Rubella (MR) di UPT BLUD Puskesmas Gunungsari. Adapun distribusi frekuensi dan persentase tingkat pengetahuan ibu tentang imunisasi vaksin Measles Rubella (MR) di UPT BLUD puskesmes gunungsari.

Dari hasil penelitian diperoleh bahwa mayoritas responden memiliki tingkat pengetahuan tentang imunisasi Measles Rubella (MR) dalam kategori baik sebanyak 36 responden (43,9\%), diikuti dengan tingkat pengetahuan dalam kategori cukup sebanyak 34 responden $(41,46 \%)$, diikuti lagi dengan kategori kurang ada 9 responden (I0,98\%), kemudian dalam kategori sangat baik ada 2 responden $(2,44 \%)$ dan yang terkecil ibu dengan tingkat pengetahuan dalam kategori sangat kurang sebanyak I responden (I,2\%). Dan di ketahui nilai rata- rata responden sebanyak 58,8\% , di katakan berpengetahuan cukup.

Berdasarkan penelitian (Yusniar, 20I2) pengetahuan responden tentang imunisasi dapat dipengaharuhi oleh karakteristik ibu yang berbedabeda. Pengetahuan responden yang baik karena responden aktif dalam kegiatan imunisasi dan mengikuti penyuluhan yang dilakukan oleh tenaga kesehatan. Selain itu pengetahuan ibu dapat diperoleh dari pengalaman ibu atau diri sendiri maupun orang lain yang pernah mengimunisasikan bayinya dan juga dapat diperoleh dari petugas kesehatan atau pelayan kesehatan (bidan) yang memberikan imunisasi pada bayi ibu.

Penelitian ini sejalan dengan peneliti yusniar (20I2) bahwa pengetahuan merupakan hasil dari tahu dan hal ini terjadi setelah seseorang melakukan pengindraan terhadap suatu objek tertentu. Pengindraan ini terjadi melalui pengindraan manusia, yaitu indra penglihatan, pendengaran, penciuman rasa dan raba. Sebagian besar pengetahuan manusia melalui mata dan telinga.

\section{SIMPULAN}

Beradarkan hasil penelitian diatas bahwa tingkat pengetahuan ibu tentang imunisasi vaksin Measles Rubella (MR) UPT BLUD Puskesmas Gunungsari dapat dikategorikan berpengetahuan baik sebanyak $43,9 \%$, diikuti dengan tingkat pengetahuan dalam kategori cukup sebanyak 4I,46\%, diikuti lagi dengan kategori kurang sebanyak I0,98\%, kemudian dalam kategori sangat baik sebanyak 2,44\% dan yang terkecil ibu dengan tingkat pengetahuan dalam kategori sangat kurang sebanyak I,2\%. Jadi dapat disimpulkan bahwa tingkat pengetahuan ibu di Puskesmas
Gunungsari secara rata-rata dikatakan berpengetahuan cukup $58 \%$

\section{REFERENSI}

Amin, A. f., damayanti, s., \& rahmawati, v. a. (2017). Moderasi islam terhadap penggunaan vaksin measles rubella (MR) pada masyarakat multikultural.

Arikunto. (2006). Presedur Penelitian Suatu Pendekatan Prokter. Jakarta: PT.Rineka Cipta.

Budiman, \& Riyanto A. (2013). Kapita Selekta Kuisioner Pengetahuan Dan Sikap Dalam Penelitian Kesehatan . Jakarta: Salema Medika 66-69.

Depkes. (2018, Agustus kamis). Fatwa Mui bolehkah imunisasi campak dan rubella, kemenkes fokus turunkan beban dan danpak penyakit tersebut.

Ditjen P2P. (2016). Petunjuk Teknis Kampanye Imunisasi Measles Rubella(MR). Jakarta: Kemenkes RI.

IDAI. (20I5, juli). Melengkapi dan mengejar imunisasi. htt://idai/publicarticles/klinik/imunisasi/melengkapimengejar imunisasi-bagian-i.html, hal. bagian I. Jakarta.

IDAI. (2017). imunisasi campak-Rubella(MR).

IDAI. (20I8). Menyooti Kontroversi Seputar Imunisasi.

IDAI. (t.thn.). Melengkapi dan mengejar imunisasi . hal. bagian I.

Kemenkes. (20I8, juli Kamis). Imunisasi Measles Rubella Lindungi Anak Kita.

Kutty, P. e. (20I3). Measles. VP D Surveillance Manual, Volume 6.

Lisnawati, L. (20II). Generasi Sehat Melalui Imunisasi, Trans Info Medi. Jakarta.

McGee, P. (20I3). Measles,mumps, and rubella. Diversity and Equality in Health and Care, Volume I0, I23-5.

Nazme, N.I.,Hoque,M.M, \& Hussain,M.,. (20I4). Congenital Rubella Syndrome. An Overview of Clinical Presentations in Bangladeshi Chlidren.Dealta Med College, Volume 2, 42-47.

Notoatmojo, S. (2007). Promosi Kesehatan Dan Ilmu Perilaku. jakarta: Rineka Cipta.

Proverawati, Atikah, \& citra Setyo Dwi Andini. (2010). Imunisasi di Indonesia dan Vaksinasi. Yogyakarta: Nuha Medika.

Rosanda., I. (2010). Cara Benar Merawat Anak. Nuha Medika. Yogyakarta. 
Satiatava, P. (20I2). asuhan neonatus bayi dan belita untuk keperawatan dan kebidanan. Jogjakarta: D-MEDIKA.

Sugiyono. (2012). Metode Penelitian Kuantitatif dan Kualitatif dan $R \& D$. Bandung: 61.

syarifuddin, A. (2009). Imunisasi Anak Cara Islam. 48. penebit tiga satu tiga.

WHO. (20I7, juni kamis). Status Campak dan Rubella saat ini di indonesia. http://WWW.searo. who.int/indonesia/t opics/immunization/mr_measles_status.p $d f$ ?ua $=I$.

Yusniar. (2012). Gambaran Tingkat Pengetahuan Ibu Mengenai Imunisasi. 